\title{
SPRING QUARTERLY MEETING, 1978
}

The Spring Quarterly Meeting was held in Dublin on 25 and 26 April 1978 under the Presidency of Professor W. LINFORd Rers and by kind invitation of the Irish Division of the College.

\section{Scientific Meetings}

The scientific meetings were held at St Vincent's Hospital, and the following papers were presented:

Tuesday 25 April

Jonathan Swift-Paradoxical Philanthropist, Professor Norman Moore.

What is meant by Success in the Treatment of Alcoholism, Dr Patrick Tubridy.

Irish Psychiatry in Historical Perspective, Professor Robert Daly.

The Evolution of a Mental Health Service: Retrospect and Prospect, Professor Ivor Browne and Dr Dermot Walsh.

The Use of Androgen or Tranquillisers in Combination with Counselling for Female Sexual Dysfunction, Dr P. A. Carney.

Epilepsy: Recent EEG Research, Professor G. W. Fenton.

\section{Wednesday 26 April}

The Mechanisms of the Anti-psychotic Effect and the Pathogenesis of Schizophrenia, Dr T. J. Crow.

Drug-Induced Depression, Dr M. W. P. Carney.

Physical and Mental Diseases Associated with High Suicide Rates, Dr B. Barraclough.

A Longitudinal Study of Neurosis in the Elderly, Dr A. A. McKechnie.

The Use of the EMI Scanner in Elderly Psychiatric Patients, Dr Robin Jacoby.

Rehabilitation of the Demented Elderly, Ms Jane Volans.

Transmitter Systems in Senile Dementia and Old Age: Post-mortem Brain Biochemistry, Dr Elaine Perry.

Patterns of Alcohol Abuse among Psychogeriatric

Patients, Dr David Marshall.

The Elderly Mentally Infirm in various Residential Settings, Dr David Wilkin.

Bi-polar Affective Illness in the Elderly, Dr Kenneth Shulman.

At the meeting of the Psychotherapy Section, Dr Dermot J. Wood presented a paper entitled, 'OutPatient Large Group Psychotherapy: Phenomenology and Effectiveness.'

Members of the Mental Deficiency Section visited St Augustine's Hospital, Blackrock.

\section{Business Meeting}

The Business Meeting was held on 26 April. ObITUARY

The Registrar announced with regret the death of the following members:

Angus Ian Alexander, Prison Medical Officer, Strangeways, Manchester.

Daniel Peter Hennessy, Consultant Psychiatrist, Rainhill Hospital, Liverpool.

Nern Mathirson MacFadyen, Veterans Administration Center, Leavenworth, Kansas, U.S.A.

John David Pryce, Assistant Physician, Westminster Hospital, London.

Patrick Joseph Campreil, St Columba's Hospital, Sligo, Ireland.

Francis Ghardes Napier, formerly Medical Superintendent, Hellesdon Hospital, Norwich.

\section{Minutes}

The Minutes of the previous meeting held in London on 8 February 1978 and published in the Bulletin, April 1978, were approved as a correct record and signed by the President.

\section{REgISTRAR's REPORT}

Dr Markowe read the following Report:

'The recent ballot has resulted in the election of Professor Desmond Pond to succeed Professor Linford Rees as President, and he will take office in July at the Annual Meeting in London.

Since my last Report Council, the Executive and Finance Committee and the Court of Electors have met regularly and have dealt with numerous matters. Some of the Reports referred to then have now appeared in print in the Bulletin, including the Memorandum on the Use of Corporal Punishment in Schools and the Memorandum on Mental Handicap. The Memorandum on Infanticide, prepared in response to a request from the Criminal Law Revision Committee; comments on the Interim Report of the Treatment and Rehabilitation Working Group of the Advisory Council on the Misuse of Drugs; and the Memorandum on the Organization of the Remedial Professions will be published very soon.

At the request of the Home Office, a Special Committee under the Chairmanship of Dr Hyatt Williams prepared a Memorandum of Evidence for the Committee on Obscenity and Film Censorship. This was presented to Council at its recent meeting, but there was also a minority report as it became 
obvious that there were nearly as many opinions as there were members of Council, and it was felt that this was not really a subject on which there could be a "College view". It was therefore agreed that the Memorandum, including the minority report, should be sent to the Home Office as a submission by the Working Party and over their signatures.

The proposals for revisions in the Bye-laws, which you approved at our last meeting, have been submitted to the Privy Council, and it is hoped that approval may be forthcoming in time for the changes to take effect after the Annual Meeting in July.

The Executive and Finance Committee and Council have also approved Memoranda on the Role, Responsibilities and Work of the Child and Adolescent Psychiatrist; Joint Appointments between the National Health Service and the Prison Medical Service; and the COHSE Report on the Management of Violent or Potentially Violent Patients, and these will be appearing in the Bulletin. A Special Committee, under the Chairmanship of Dr Brian Ward, prepared comments on the Report of the Joint Working Party to Formulate Ethical Guidelines for the Conduct of Programmes of Behaviour Modification (the Zangwill Committee) and these comments were approved by Council; much of the Report was welcomed, but the proposals for the setting up of Review Bodies were considered unacceptable.

At its meeting in two weeks' time the Executive and Finance Committee will be considering the comments of the Mental Deficiency Section on Local Authority Day Services for Mentally Handicapped Adults (National Development Group's Pamphlet No. 5) and the First Report of the Development Team for the Mentally Handicapped. The Social and Community Psychiatry Group is preparing recommendations on the Rehabilitation of Long Stay Patients; Interim comments have been sent to the DHSS on proposals for revised procedures to record consent to and participation in Clinical Research Investigations, and a more detailed submission is now being prepared by the Research Committee. The Child Psychiatry Section is preparing comments on the DHSS Consultative Document on the Adoption Service. A Special Committee under the Chairmanship of the President is considering the provision, or lack of provision, of Regional Security Units.

The Court of Electors has recently elected new Fellows, whose names will be published in the Bulletin. The Court is also discussing new procedures to streamline the method of receiving and considering nominations for the Fellowship and to ensure that no worthy candidates are overlooked. You will have recently seen in the Bulletin "A Note from the President" on the ways in which the College makes its recommendations for Distinction Awards. The College Awards Committee will meet next month to draw up its recommendations for the current year.

The College has welcomed the setting up by the World Psychiatric Association of a Committee to Review the Abuse of Psychiatry and also a Committee on Ethics, and it is hoped that these will soon be functioning. In the meantime there have been a number of reports of the abuse of psychiatry and illtreatment of psychiatrists in the handling of political dissenters both in Russia and in the Argentine, and these have been referred to the Public Policy Committee who will be making recommendations to the Council or the Executive and Finance Committee about any useful action the College could or should take.

The firm which supplied the College's minicomputer has let us down badly in that it should have been working by I September last year and very great efforts were made by our staff to see that all the information needed was prepared. In the event the programming is not yet completed. We are taking advice from various sources, including our solicitors and other professional advisers who helped us in the decision to purchase a computer.

Finally, on a happy note, we are very grateful to our Irish colleagues for all they have done to make this Quarterly Meeting an outstanding success both scientifically and socially and for giving some of us at least an opportunity to see something of the lovely City of Dublin and your countryside. We are especially indebted to the officers of the Irish Division: the Chairman, Dr John Fennelly and the Secretary, Dr Kenneth Sinanan, to Professor Walsh for the arrangements here at St Vincent's Hospital and for Lunch at Elm Park, and to Dr Mary Sullivan and Dr Desmond McGrath. We are also most grateful to the Irish Tourist Board for the splendid reception on Monday evening and the opportunity of seeing the so impressive National Gallery of Ireland; and to the Minister of Health and Social Welfare, Mr Charles Haughey, for last evening's magnificent Government Reception. Tonight we hope to welcome some of our hosts as guests at a Banquet at Trinity College. Lastly it is rumoured that some members are absconding to the Golf Course tomorrow-we hope they will have an enjoyable day on the famous course at Portmarnock.' 